\title{
资产管理视角下的景观设计 LANDSCAPE DESIGN AS AN ASSET MANAGEMENT
}

林玮
清华大学公共管理学院博士候选人
上海市闵行区新镇路1399号宝龙总部大廈 $5 F$, 邮编: 201101
busylinwei@sina.com

\section{1 作为资本逻辑一环的景观}

景观是人类经济活动的产物。与土地 和建筑一样, 景观可以被视为一种资本投 人, 进而作为生产资料塑造人们的生产生活 环境。景观的形成受限于生产力水平与生产 关系: 一方面, 创造景观所采用的工具、材 料、工程技术, 以及审美视角都无法脱离当 地的经济发展水平; 另一方面, 大部分景观 创造活动一一无论是公共工程还是私有工 程一一都是在市场中通过采购方/业主方的招 标邀标, 向设计规划与建筑施工单位实施的 购买行为。景观创造本身就是服务交易中的 一环, 也必定符合资本逻辑: 只有获得了买 造持续利益

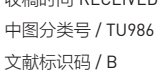
图分类号 / TU986 文献标识码 / B

摘要

景观是人类经济活动的产物, 亦可被视作一种资产, 其形成受限于生 产力水平与生产关系。无论是自持、销售物业，还是政府公共项目，设计 都需要考虑租金回报、公众满意等全生命周期利益流入。本文提供了以资 产管理的思路理解景观的独特视角, 并指出了在从设计到使用的全生命周 期中, 资产管理所扮演的角色一一其介入有助于基于不同阶段和不同群体 的利益对设计方案进行平衡与协调。除借助资产管理方的帮助外, 设计师 也应加强产品思维与用户思维, 通过轮岗、跨部门联席会议、项目制组织 等机制掌握通识与交叉业务知识, 藉由早期全局介入和使用后评估及时评 估运营结果, 以复盘教训、改良成果。

关键词

资产管理; 景观设计; 使用后评估; 全局观; 经济

\section{ABSTRACT}

Landscape is a product of economic activities and an asset associated with a society's productivity levels and the relations of production. Despite the range of projects - self-owned, for-sale,or public infrastructure

- that designers undertake, life-cycle benefits such as rental returns and public satisfaction should always be considered. By interpreting landscape design as an asset management, this article highlights the third-party role of asset managers who coordinate the benefits of all stakeholders at different stages through negotiation of design options. Designers are also expected to have a product and user thinking, acquire general and interdisciplinary knowledge of certain businesses through role rotations, cross-department meetings, and diverse project teams to improve design proposals, and strengthen mechanisms of pre-occupancy engagement and post-occupancy evaluation.

2 资产管理的作用: 统筹多元需求, 创

狭义的“资产” 即企业资产负债表中 的资产端，通过既往的购买或生产过程而得 以形成，其根本特征在于可以带来未来的利
Asset Management; Landscape Design; Post-Occupancy Evaluation; Holistic Thinking; Economy

译萨拉·雅各布斯 田乐

EDITED BY WANG Moying SHE Yishuang

TRANSLATED BY Sara JACOBS Tina TIAN
整理 汪默英 余依爽 
(1) 由于中国内地和中国 香港地区采取土地公 有制和批租制度, 因 此国内住宅除居住属 性外, 也具有入股城市 发展的“城市股票” 属 性, 这也是另一种“价 值” 体现。

(2) 不同人群的效用函数 不同。例如, A对甲更 有价值、B对乙更有价 值, 通过等价交换, 甲 对A出更高价、乙对 $B$ 出 对A出更高价、乙对B出
更高价, 就会促使甲在 自身组合中拥有更多的 A、乙拥有更多的B，从 而甲乙的总体效用在均 衡状态时达到最大化。 如果仅考虑某一方偏 如果仅考虑某一方偏 好, 而造成另一方利益 体效用最大化。

3) 品牌级次是指品牌的层 级, 例如奢侈品、轻 奢、设计师精品店、大 众快消、普通杂牌等。

(4) 对于大部分项目来说, 对标理想回报率主要通 过投资回收期、内部收 益率、净运营收入等经 济指标反映。部分公共 济指标反映。部分公共 育场馆等) 也包括活动 承载量、服务范围等外 部效应。
益流人。景观作为资产所产生的持续利益流 人，在各种类型的项目中均有体现：1）商 业地产的成果大部分为开发商自持, 需要通 过服务商户与消费者获得租金、物业管理费 等持续现金流人，因此项目运营显得尤其重 要。2 ) 住宅地产主要用于销售, 为了尽快获 取最多的当期回款, 需竭尽全力满足消费者 在住宅全生命周期内对宜居、美观等方面的 需求。可以说, 营销部门所欲实现的资产价 值, 即代表着消费者愿意为居住空间付出价 值的折现 ${ }^{[1]}$ 。3) 公共工程的持有者是政府或 政府注资平台, 其可以通过租赁方式获取租 金或运营方的收人提成，但更重要的是供公 众免费使用以实现其公共价值。这类工程的 资产价值（包括公共价值）即投资、设计、 运营、使用等各方参与者的效用函数 ${ }^{2}$ 达到均 衡时的总体福利大小。

在进行具体设计时，虽然不能盲目追 求利益最大化, 但也不能因对艺术和创新的 需求而忽视其经济性。例如，虽然以“按最 高盈利强度排布建筑总图 (强排) ”为代表 的服从于强大资本意图而忽视人居尺度或美 学价值的设计方式不可取, 但从开发商的角 度出发, 如果无法高强度利用土地, 便难以 达到必要的资金周转效率，其后续市场运作 也会受到影响。多数开发商不愿意为所谓的 “人居尺度” 买单，实际上也是因为对于绝 大多数消费者来说, 空间品质的重要程度 (与价格等因素相比) 相对靠后, 因此也并 不愿为此支付溢价。所以，在预算一定的条
件下, 开发商更愿意追求低成本和高效率。

“资产管理” 即通过被动监控预警和 主动管理提升，提高资产创造未来利益的能 力一一无论这种利益是直接的现金流人, 还 是更高的用户满意度所带来的间接利益。资 产管理不是工程监理、物业管理、场地运营 等现场工作, 而是以独立第三方的立场, 从 业主未来利益角度来计算得失、设定收支, 并聘请、督促执行团队达成目标。

在房地产信托投资基金（REITs）市场较 为成熟的区域，会设立资产管理经理岗位， 其人选一要懂市场, 能够根据用户画像了解 用户需求以及变化中的市场/公众需求，提出 设计和运营目标; 二要懂金融，能够为该项 目的融资及后期退出制定预设方案; 三要懂 设计, 能够评估各种方案的可行性并核算成 本。在中国，由于没有成熟的REITs市场，大 部分项目的业主方同时也是运营方，因此多 会外聘专业人士或者内设相对独立的资产管 理部门来执行上述工作。

受益于这种第三方立场，资产管理团 队可以纵贯从投资拿地、定位规划、深化设 计到施工销售、持有运营、转让退出等全生 命周期; 亦可以从回报分析角度协调前端投 资决策方，中端规划设计、开发建造方，以 及终端用户方等各方利益。例如，在商业景 观的设计中，资产管理团队可根据用户需求 与市场定位，提供景观成果的愿景画像，监 控设计成果对租售情况、区域活力、交通动

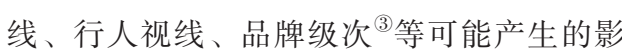

响, 并将建造成本控制在合理范围内。这种 合作关系也对景观设计师的能力提出了新的 要求: 除了工程思维和艺术思维外, 也必须 培养产品思维和用户思维, 掌握通识与交叉 业务知识。对正、反面案例的使用后评估有 助于设计师培养上述能力。

\section{3 在景观设计中融合资产管理视角：使 用后评估与早期全局介入}

以资产管理视角参与景观设计, 不仅需 要对过往项目回报得失进行 “马后炮” 式的 分析判断, 也需要在一定程度上预见设计成 果与周边社区和用户需求的契合程度，进而 评估投资回报。

\section{1 使用后评估中的设计循环}

使用后评估（POE）的概念多年前就已 被提出, 其经典定义是 “人类使用者对已经 投人使用的建成环境的效能的检测” ${ }^{[2]}$ 。沃夫 冈 $\cdot \mathrm{F} \cdot \mathrm{E} \cdot$ 普莱泽尔认为, “ $\mathrm{POE}$ 是场地管 理者的系统性诊断工具, 使其能够系统识别 和评估若干关键层面的建筑绩效。除了确定 建成建筑的问题所在, POE亦可测试新的建 筑物原型, 并为待建设施制定设计指南和标 准” ${ }^{[3]}$ 。目前的建筑POE研究大多偏向于关注 使用者社会学、心理学上的行为习惯、舒适 程度等 ${ }^{[4]}$, 而忽视了建筑投资回报的整体评 估, 以及与对标理想回报的距离。而相对较 晚开展的景观 POE则多是针对城市公园与绿 
地进行的个案研究 ${ }^{[5] 6]}$, 这些评估往往关注设 计与使用者习惯之间存在的冲突, 较少从经 济角度出发, 信息来源也主要依赖观察、问 卷、访谈等主观性较强的途径, 而非客观的 运营数据 ${ }^{[7] 18]}$

从资产管理的视角来看, 复盘过程会 特别重视人流吸引情况和商业业态分布是否 符合设计预期; 如果不符合, 则考虑是否是 因为预留工程条件、车位规划、动线设计、 休尓空间设计, 乃至导视互动设计出现了问 题。对于这些问题的POE, 除了需要设计方 提高自我学习和快速迭代的意识, 主动搜集 评估资料外, 更加理想的方案是由第三方资 产管理者来搜集各方反馈, 监控实际运营, 反馈数据, 并以数据为依据提出明确的评估 改进意见。

\section{2 早期全局介入}

设计是 “多重目标+多重限制” 的复杂决 策过程, 除了在投资研判阶段展开对当地经 济、交通、人文、社会等层面的调研外, 更 需要从营销和商业运营等角度来主动思考需 求 ( 提高客流量、人驻率、区域活力, 以及 业态平衡等) ; 理解市民/消费者的需求 ( 尺 度空间适宜、标识系统清晰、洗手间等公共 设施宽敞洁净、休闲空间舒适宜人等); 理 解政府的需求 ( 提升城市形象、周边土地增 值、创造就业机会等）; 理解投资人/业主方 的需求 (较短的投资回报期、较高的内部收 益率和静态租金回报率等）。
要想具备全局观, 除借助第三方资产管 理的帮助外, 保障机制的建立也十分重要。 这种机制一般包括: 1) 适当的短期轮岗, 以 类似 “售后工程师” 的角度参与日常后端运 营, 获得感性认知；2）跨部门联席会议, 如 要求后端部门参加设计方案制定会议并拥有 投票权、否决权等； 3 ) 项目制的人员组织 结构, 即在为各个项目临时组建的项目组中 安排来自不同部门、具备不同学科背景的成 员, 以加强相互理解并加快纠偏机制的迭代 速度。

\section{4 结语}

本文提供了以资产管理的思路理解景 观设计的独特视角, 并指出了在从设计到使 用的全生命周期中, 资产管理所扮演的角 色——其介人有助于基于不同阶段和不同群 体的利益对设计方案进行平衡与协调。资产 管理团队与景观设计团队既可以是相互合作 的关系, 也可以是后者包含前者的关系。景 观设计师一方面需要建立从资产管理视角认 识景观、注重经济效益的意识; 另一方面, 也应积极培养自身的跨学科统筹能力及综合 实力。笔者认为, 目前较为可行的培养路 径即是通过早期全局介人与POE进行快速学 习。在多方合作语境或跨学科考量下, 该路 径将使得景观设计成果更优、回报更好, 取 得各方满意的共赢结果。LAF 
Mainland China and Hong Kong, China hav adopted public land ownership and lease holding, which endow domestic residential building with "city equity shares" to reflect another value of residential buildings.

The utility function varies for different varies for dirterent parties. If $\mathrm{A}$ is more valuable to one while $B$ is more valuable to another, based on the rule of equivalent exchange, the former one pays more for $\mathrm{A}$ and the latter pays more for $B$, thus maxizing the overall maximizing the overal utility in a balanced state. The maximization of general utility cannot be realized if only one party is favored.

\section{A Capital Logic}

Landscape is a product of economic activities. Like land or buildings, it is a capital investment and the means of production that shapes our daily lives. The creation of landscape is associated with a society's productivity levels and the relations of production. The tools, materials, engineering technologies, and aesthetic perspectives that create landscapes are largely depended on local economics. Most landscape planning and design work - whether it is public or private - is commissioned through open tender or invitation. As a service trade, the creation of landscape follows the capital logic. The value of a design is not realized unless it is acknowledged by the client and proved to be efficient in its life-cycle. The final landscape is the result of both sides working together. Also, in a free market economy, the capital logic such as exchange at equal value necessitates the intervention of asset managers.

\section{Coordinating Diverse Needs and Long-Term Benefits through Asset Management}

Asset refers to previous buying or production activities on a balance. The fundamental feature of an asset is that it can generate future benefits. The long-term asset benefits of designed landscapes can be found in many types of properties, including commercial properties owned by developers, who receive rental returns and property management fees from commercial tenants and consumers. Project operation is therefore of particular importance. Other properties, including residential properties, are required to meet the livability and aesthetic needs of consumers while maximizing the returns. In other words, the asset values achieved through marketing represent the price that the residents are willing to pay for living spaces ${ }^{[1]}$. Finally, public projects owned by the government can realize their economic value in the form of rental returns or royalties and, more importantly, these projects' asset values, including public value, can be accessed by the public and assessed by the general welfare when the utility functions ${ }^{2}$ of all stakeholders, including investors, designers, operators, and users, reach an equilibrium.

Landscape designers cannot chase only economic benefits or simply develop innovative ideas for an artistic value. Developers tend to choose the design strategies based on capital potential rather than liveability or artistic standards, even if they know that is not the best choice. Capital returns can be hard to achieve if the land is not high-density enough, which would undermine developers' followup investments and operation. In fact, despite developers, customers also consider the quality of living space after price. With a limited budget, developers focus on chasing a higher cost-efficiency and a greater return of investment.

Asset management can enhance asset capabilities and future benefits, including increasing direct cash flow and indirect user satisfaction, through both passive (like supervision) and active (like management) methods. Unlike project supervision, property management, or site operation, asset management acts as a third party to help calculate incomes and expenses and set goals for future investments and returns, executed by an outsourcing team sometimes.

An asset manager running a mature Real Estate Investment Trusts (REITs) is expected to know the market and can propose design and operational goals based on customer insights and the changing market demands. Financially, an asset manager can assist with project 
fund-raising, clearance, and closure.

Finally, an asset manager can evaluate design feasibility and cost. China does not have a mature REITs market and most proprietors work as project managers, hiring external professionals or establishing an independent own asset management agency.

The asset management team is an independent party who can work with the entire project lifecycle from land market investments, planning and design, to construction, sale, operation, and possession transfer or money withdrawals. The asset manager can also take responsibility for coordinating interests from investors, designers, developers, contractors, and users. In commercial projects, for example, an asset management team can coordinate with the landscape design by providing a scenario according to users' demands and market projections, which estimates the impacts of design proposals on rent and sale potential, neighborhood vitality, traffic movement, visual effects, and commercial hierarchy ${ }^{3}$, and setting a reasonable budget. Growing relationships between asset managers and landscape designers create new challenges and requires for the latter, who have to train themselves with a product and user thinking and to learn general and interdisciplinary knowledge, in addition to improving their engineering and artistic capabilities. The post-occupancy evaluation of both good and bad design examples is an effective path for designers to acquire these skills.

\section{Asset Management in Landscape Design: Post-Occupancy Evaluation and Pre-Occupancy Engagement}

Asset management in landscape design process requires post-occupancy evaluation on completed projects, as well as pre-occupancy engagement which could inform design decisions to achieve a sounder social and economic performance.

\subsection{Design Cycle Created by Post- Occupancy Evaluation}

The concept of post-occupancy evaluation (POE) was proposed years ago, referring to "an examination of the effectiveness for human users of occupied built environments." ${ }^{[2]}$ According to Wolfgang F. E. Preiser, "POE is a diagnostic tool and system which allows facility managers to identify and evaluate critical aspects of building performance systematically. These evaluations have been used to identify problem areas in existing buildings, to test building prototypes, or to develop future design guidelines." ${ }^{[3]}$ Current POE studies of architecture focus on users' behavioral habits and comforts drawn from sociology and psychology ${ }^{[4]}$, and neglect overall assessment of investment returns and gaps between real and benchmarking ideal return ${ }^{(4)}$ Current post-occupancy evaluations on landscape projects consist mostly of case studies on city parks and green spaces $^{[5][6]}$, which take into account conflicts between design and use but fail to consider economic factors. Information is gained from observation, questionnaires, and interviews, instead of operation data ${ }^{[7][8]}$.

Asset management focuses on the distribution of commercial uses to meet design expectations by examining redundant technical conditions, parking planning, mobility, rest space, and signage or interpretation system. Ideally, POE should be carried out by third-party asset managers who collect feedback from stakeholders, monitor operations, contribute feedback data, and propose targeted improvement ideas. POE helps designers update
A commercial hierarchy consists of luxury, mild street, and inferior brands.
(4) In most cases, the benchmarking ideal return rate is reflected by economic indicators including investment return period, interna return period, intera rate of return, and net ope Especially in public projects such as traffic facilities and sports stadiums, event carrying capacity, service radius, an other external affects can also partly reflect the rate.


knowledge and inform design decisions in future.

\subsection{Pre-Occupancy Engagement}

Design is a complicated decisionmaking process that involves multiple goals and limits. In addition to local economic, transportation, and cultural investigations during the investment and research stages, reflections focusing on marketing and commercial operation phases such as how to enhance population flow, occupancy rate, and regional vigor and balance business format is required. It is also necessary to understand the needs of citizens / consumers such as spatial comfort, understandable guidance, and highquality leisure space. For governments, these considerations include enhancing city image, land appreciation, and job creation. Finally, for investors, shortterm investments with a good internal rate of return and a steady-state rental yield is important.

To gain a holistic view, designers need to follow a guarantee mechanism. This includes: 1) shortterm job rotations to become involved in post-occupancy daily operations and gain direct perception from real practices; 2) regular cross- department meetings, such as having a post-occupancy department engage in the design process and involve their suggestions; and 3) project-based teams that are composed of members from different departments and backgrounds to deepen mutual understanding and promote the update of a deviationrectification system.

\section{Conclusion}

This article proposes interpreting landscape design from an asset management perspective and highlights the role of asset managers who better coordinate the benefits of different stakeholders at different stages through examination and adjustment of design options. An asset management team can work with landscape teams or be integrated into them. Landscape designers should view landscapes from the perspective of asset management and value the economic benefits, while developing their crossdisciplinary abilities. Pre-occupation engagement and POE are feasible for landscape designers. With cooperation among multiple stakeholders and interdisciplinary professionals, landscape design will achieve win-win results. LAF

\section{REFERENCES}

[1] Zhao, Y. J. (2016). State Credit and Land Finance: Chinese Urbanization in Transition. Urban Development Studies, (12), Urbanizat.

[2] Zimring, C. M., \& Reizenstein, J. E. (1980). Post-Occupancy Evaluation: An Overview. Environment and Behavior, 12(4), 429-450.

[3] Preiser, W. F. E. (1995). Post-Occupancy Evaluation: How To Make Buildings Work Better. Facilities, 13(11), 19-28.

[4] Wang, Z. H., Zhan, W., \& Fu., Q. (2010). Research Progress of Post-Occupancy Evaluation. Wuhan: 2010 International Conference on Computer Science and Sports Engineering Conference
(CSSE).

[5] Li, Y. T. (2016). Application of Post-Occupancy Evaluation Methodology in Comprehensive Urban Park Landscape Design: A Case Study of Zhongshan Park, Xiamen. Guangdong Landscape Architecture, (6), 50-56.

[6] Gao, Y. S., Zhou, B., \& Yang, J. (2018). Post Occupancy Evaluation (POE) on the Rural Greenway System: A Case Study of Jinjiang 198 LOHAS Greenway in Chengdu, Sichuan Province, Chinese Landscape Architecture, 34(2), 116-121.

[7] Huang, J. W., \& Dong, J. J. (2016). Post-Occupancy Evaluation of Campus Landscape Space: A Case Study of Huaqiao University. Guangdong Landscape Architecture, (4), 57-63.

[8] He, J. J., \& Wang, W. (2018). Post-Occupancy Evaluation of Urban Scenic and Historic Area - A Case Study of Langya Moutain Scenic and Historic Area in Chuzhou. Journal of Shanghai Jiaotong University (Agricultural Science), (4), 72 